\title{
Effect of Boiling and Wet Frying on Nutritional and Antinutrients Content of Traditional Vegetables Commonly Consumed in Malawi
}

\author{
Joseph Y. Issa ${ }^{1,2}$, Arnold Onyango ${ }^{1}$, Anselimo O. Makokha ${ }^{1} \&$ Judith Okoth $^{1}$ \\ ${ }^{1}$ Department of Human Nutrition Sciences, School of Food and Nutrition Sciences, Jomo Kenyatta University of \\ Agriculture and Technology, P.O. Box 620000020 Nairobi, Kenya \\ ${ }^{2}$ Centre for Innovation and Industrial Research, Malawi University of Science and Technology, P.O.Box 5196, \\ Limbe, Malawi \\ Correspondence: Centre for Innovation and Industrial Research, Malawi University of Science and Technology, \\ P.O.Box 5196, Limbe, Malawi. E-mail: jissa@ must.ac.mw
}

Received: August 9, 2019

Accepted: October 29, 2019 Online Published: November 7, 2019

doi:10.5539/jfr.v9n1p19

\author{
URL: https://doi.org/10.5539/jfr.v9n1p19
}

\begin{abstract}
This study was carried out to evaluate the effects of boiling and wet frying on nutritional and antinutrients content of Amaranth hybridus, Moringa oleifera, Bidens pilosa (black jack), Corchorus olitorius (Jute mallow) and Ipomea batatas (sweet potato) leaves. The edible portions of the vegetables were either boiled or wet fried for ten minutes then dried alongside the raw vegetables under the shade. Crude fats, minerals, vitamins and antinutrients were determined in the dried materials. Wet frying increased the oil content of the vegetables by a range of $15.49 \%$ to $28.40 \%$ and was hence associated with lower $\%$ ash and mineral contents. Wet frying significantly reduced $(\mathrm{P} \leq 0.05)$ beta-carotene in all the vegetables except in jute mallow. Boiling had no significant effect on beta-carotene in most of the vegetables. Boiling significantly reduced $(\mathrm{P} \leq 0.05)$ ascorbic acid in all the vegetables while wet frying preserved ascorbic acid in all the vegetables. Both boiling and wet frying significantly reduced $(\mathrm{P} \leq 0.05)$ oxalates in all the vegetables except in black jack. Both boiling and wet frying significantly $(\mathrm{P} \leq 0.05)$ reduced the concentration of phytates in most of the vegetables. However, boiling was more effective in reducing the amount of phytates. Boiling reduced higher concentrations of tannins in all the vegetables as compared to wet frying. Boiling was associated with better retention of minerals and beta-carotene, and greater reduction of antinutrients in most of the vegetables. Wet frying was more advantageous in retaining vitamin $\mathrm{C}$. The different species showed differences in retention of various minerals and vitamins.
\end{abstract}

Keywords: Vitamins, minerals, anti-nutrients, boiling, wet frying, traditional vegetables, Malawi

\section{Introduction}

Vegetables are the most affordable source of minerals and vitamins for families in most developing countries (Kenya Demographic Health Survey, 2014). In Malawi, most households especially from the rural and peri-urban areas depend on plant based food and vegetables as source of minerals and vitamins ( Cathoric Relief Services [CRS], 2017). Traditional leafy vegetables are widely utilized in Malawi and thus play a big role in contributing to nutrition. Leafy vegetables are rich sources of iron, pro-vitamin A (beta-carotene), vitamin C and zinc among other vitamins and minerals (Maundu, 2014).

According to the assessment survey conducted by CRS, (2017), the following traditional vegetables are widely consumed and preferred within the southern region of Malawi: Amaranth, Corchorus olitorius (jute mallow) leaves, Moringa oleifera, Ipomea batatas (sweet potato) leaves, Bidens pilosa (black jack) leaves, pumpkins leaves, Cleome gynandra leaves and cowpea leaves. Among these, Amaranth, Jute mallow, Black jack and Cleome gynandra plants grow wildly in the bush or as weeds in the fields.

Farmers harvest these traditional and wild vegetables in the bush and the gardens for consumption and sale. Sweet potato leaves, pumpkins leaves and cowpea leaves are harvested from the cultivated fields and are consumed or sold as vegetables. These commonly consumed vegetables in Malawi play a big role in contributing to health and nutrition through the vitamins and minerals that they possess. According to CRS, (2017), Amaranth leaves are nutritionally rich in calcium, iron, beta carotene and ascorbic acid; sweet potato leaves leaves are rich sources of iron, ascorbic acid and beta carotene; black jack leaves are rich in beta carotene, iron, Zinc and 
ascorbic acid; Cleome gynandra leaves are rich sources of ascorbic acid, beta carotene, folic acid and calcium; Moringa oleifera leaves are rich sources of beta carotene, vitamin E, iron, folic acid and calcium; and Jute mallow leaves are rich in beta carotene, iron, folic acid ascorbic acid, calcium and protein.

The nutrients being supplied by these indigenous and traditional vegetables are very important to human health and nutrition. Most of the vitamins and minerals found in vegetables such as beta carotene, ascorbic acid, iron, zinc and magnesium contributes to improvement of the immune function ( Ebrahimzadeh, M. A., Pourmorad, F., \& Bekhradnia, A. R. (2008). Beta carotene which is a precursor of vitamin A is essential for growth, development, immunity and good vision. Beta carotene and ascorbic acid also play a role of antioxidants and helps to reduce the risk of diseases related to oxidative stress such as diabetes mellitus, cardiovascular diseases and some cancers (Yang \& Keding, 2009 ; Uusiku, N. P., Oelofse, A., Duodu, K. G., Bester, M. J., \& Faber, M. (2010). Iron is essential for prevention of iron deficiency anemia which is the main causes of anemia in the world. The main risk factors of iron deficiency anemia are low intake of iron, poor bioavailability from iron food containing phytates and polyphenols (Passone, M. A., Resnik, S. L., \& Etcheverry, M. G. (2005). Zinc is also a micronutrient which is responsible for normal growth function and immune function; its biological roles are structural, as catalyst and as a regulatory ion (Etcheverry, P., Grusak, M. A., \& Fleige, L. E. (2012).

Vegetable containing diets however, may lead to reduced availability of minerals from the diets due to presence of antinutrients (Etcheverry et al., 2012). Traditional leafy vegetables are plenty in Sub-Saharan Africa including Malawi and they are known to contain anti-nutrients such as phytates, tannins, glycosides, oxalates, alkaloids and hydrocyanic acid. Tannins are identified as plant polyphenols that are capable of forming complexes with metal ions and macro-molecules like proteins and polysaccharides (Olawoye \& Gbadamosi, 2017). Tannins affect the nutritional value of food products by chelating minerals like iron and zinc and reducing the absorption of these minerals as well as forming complexes with protein thereby inhibiting their digestion and absorption (Olawoye et al., 2017). Tannins are responsible for a decrease in growth rate as well as a non-palatable taste as they contribute to protein inhibition by forming complexes (Etcheverry et al., 2012).

Phytic acid (phytates) is the major phosphorous storage compound in traditional leafy vegetables. Phytic acid has been reported to inhibit the absorption of minerals such as calcium, iron and zinc; and reduce the bioavailability of these minerals in food (Etcheverry et al., 2012). Too much of a phytate rich diet is associated with nutritional diseases such as rickets and osteomalacia or osteoporosis in children and adults (Otunola \& Afolayan, 2017) respectively.

Oxalic acid (Oxalates) exists in many leafy vegetables and plant foods. Depending on species, oxalic acid can occur as soluble salts of potassium and sodium or as insoluble salts of calcium, magnesium or iron or it can occur as a combination of soluble and insoluble salts (Essack, Odhav, \& Mellem, 2017) . This forms strong chelates with dietary calcium thereby inhibiting its absorption (Akwaowo, Ndon, \& Etuk, 2000) . It is well known that oxalic acid and its salts can have a deleterious effect on human nutrition and health, mostly by decreasing calcium absorption and aiding the formation of kidney stones (Olawoye et al., 2017).

Food processing techniques are often utilized in order to reduce antinutrients in food. Cooking is a common form of processing of plants that are consumed as a food source at household level. Some studies have suggested that different cooking methods may have different effects on different nutrients and antinutrients. Thus, the micronutrients and antinutrients are affected differently by processing, depending on the type of processing, as well as the type of vegetable species. Cooking causes changes in the phytochemistry of the leafy vegetable affecting its nutrients bioavailability and health benefit properties. The degree of these changes depends largely on the cooking methods as well as the type of the vegetable (Odhav, B., Beekrum, S., Akula, U., \& Baijnath, H., 2007).

This study was therefore conducted to investigate the effect of short time boiling and sautéing (wet frying) on nutrients retention and antinutrients content in five traditional vegetables commonly consumed in Malawi. Boiling and wet frying are the common methods of cooking vegetables in Malawi.

\section{Materials and Methods}

\subsection{Sample Collection and Preparation}

Five traditional leafy vegetables that are commonly consumed in Malawi (Amaranth hybridus, Moringa oleifera, Bidens pilosa (black jack), Corchorus olitorius (Jute mallow) and Ipomea batatas (sweet potato leaves) were used in this study. Vegetable samples were randomly collected from the gardens in the southern region of Malawi. Moringa oleifera leaves were sampled from the Moringa trees in the district of Chikwawa, Malawi. Edible portions of the fresh vegetable leaves in this study were harvested and put in the sealed plastic bags. The plastic 
bags containing the vegetables were placed in portable coolers and transferred to a laboratory at Malawi university of Science and Technology (MUST) for processing. Vegetable leaf samples were washed with tap water followed by distilled water before further processing. The vegetables were then cooked using the methods that are commonly used in Malawi, thus boiling and wet frying (sautéing). A portion of each of the vegetable samples (about 1 kilogram) was boiled in $800 \mathrm{ml}$ of distilled water for 10 minutes with frequent turning to allow even cooking in stainless steel pots. Similar portions (1 kilogram) of the samples were wet fried in $200 \mathrm{ml}$ of vegetable oil for 10 minutes with frequent turning to allow even cooking in stainless steel pots. Other similar portions (1kilogram) of the raw samples were air dried in a shade until crispy dry without cooking. The boiled and wet fried samples were also dried under shade as was done with the raw samples until crispy dry. The temperature during the drying period ranged from 29-35 degrees Celsius. Dried samples were wrapped in alluminium foils and kept in tightly closed plastic containers. All the samples were then transferred to Jomo Kenyatta University of Agriculture and Technology (JKUAT), Food Biochemistry laboratory for chemical analysis.

\subsection{Nutritional Analysis}

\subsubsection{Determination of Crude Fats}

Crude fat content was determined using Soxhlet method according to AOAC. To achieve this, $5 \mathrm{~g}$ of ground dry sample was placed in the thimble then the thimble was placed in the soxhlet extractor. Then $150 \mathrm{~mL}$ round bottom flask was cleaned and filled with $90 \mathrm{ml}$ petroleum ether. The whole setting was placed on a heating mantle to allow the petroleum ether to boil. The extraction was done for almost 6 hours. The condensing unit was then removed from extraction unit to allow the sample to cool down as it had finally removed all the lipids. The flasks containing extracted fat were then placed in the oven at $102^{\circ} \mathrm{C}$ to dry to constant weight then were placed in a desiccator before they were weighed. The $\%$ Crude fat was calculated using the following method:

$$
\% \text { Crude fat }=\left(\mathrm{W}_{2}-\mathrm{W}_{1}\right) \times 100 / \mathrm{S}
$$

Where $\mathrm{W}_{1}=$ weight of empty flask, $\mathrm{W}_{2}=$ weight of flask and extracted fat, and $\mathrm{S}=$ weight of sample.

\subsubsection{Determination of Ash and Minerals}

Minerals (zinc, iron, calcium, magnesium and copper) were determined according to AOAC (1995, Method 970: 12). To achieve this, about 2 grams of each sample was weighed and delivered into the crucibles. The crucibles were placed on a hot plate under a fume hood and the temperature was increased slowly until smoking ceased to char the samples. Samples were then put in muffle furnace and temperature was increased gradually to $250^{\circ} \mathrm{C}$ and heated for 1 hour. The temperature was then increased to $550{ }^{\circ} \mathrm{C}$ and incinerated to complete ashing. Thereafter, the temperature was decreased to $300{ }^{\circ} \mathrm{C}$, and the crucibles were removed and cooled to room temperature. The ash was measured using an analytical balance to determine percentage of ash in the samples. The ash was then transferred quantitatively to $100 \mathrm{~mL}$ beakers containing $20 \mathrm{~mL}$ of $1 \mathrm{~N} \mathrm{HCL}$, then heated at about $80-90{ }^{\circ} \mathrm{C}$ on a hot plate for 5 minutes. These were then transferred to $100 \mathrm{~mL}$ volumetric flask and were filled to the mark with $1 \mathrm{~N} \mathrm{HCL}$. Insoluble matter was filtered and the filtrate was kept in a labeled polyethylene bottles. The absorbances of the solutions were read by Atomic Absorption Spectrophotometer (AAS) Shimadzu Japan. Minerals standards were prepared at varying concentrations to make the calibration curves. Iron was measured at a wavelength of $284.3 \mathrm{~nm}$, zinc was measured at $213.9 \mathrm{~nm}$, calcium was measured at $422.7 \mathrm{~nm}$, magnesium was measured at $285.5 \mathrm{~nm}$ and copper was measured at $324.8 \mathrm{~nm}$.

\subsubsection{Determination of Beta Carotene}

Beta carotene content in the vegetable samples was analyzed using column chromatography and UV Spectrophotometer. Extraction of the carotenoids was done using acetone and petroleum ether as described by Rodriguez-Amaya, D. \& Kimura, M., (2004) . Briefly, approximately 2 grams of each sample was weighed using analytical balance and placed in a mortar with about $10 \mathrm{~mL}$ of acetone. This was followed by thorough grinding with a pestle then the acetone extracts were transferred into $100 \mathrm{~mL}$ volumetric flasks. The residues were again extracted with $10 \mathrm{~mL}$ acetone and the extracts were added to the contents of the volumetric flasks. The extraction with acetone was continued until the residues no longer gave color. The combined extracts were then made to a volume of $100 \mathrm{~mL}$ with acetone. About $50 \mathrm{~mL}$ of each extract was evaporated to dryness using rotary evaporator. The residue was dissolved with $10 \mathrm{~mL}$ petroleum ether and the solution was introduced into a chromatographic column to elute beta-carotene. The eluted beta-carotene was collected in $50 \mathrm{ml}$ volumetric flasks and made to a volume of $25 \mathrm{~mL}$ with petroleum ether. The absorbances of the solutions were read at $440 \mathrm{~nm}$ using a UV-Vis spectrophotometer. Beta carotene standards were prepared and read together with the samples at $440 \mathrm{~nm}$. 


\subsubsection{Determination of Ascorbic Acid}

Ascorbic acid content of the samples was determined by High Performance Liquid Chromatography (HPLC) method (Vikram, V. B., Ramesh, M. N., \& Prapulla, S. G. (2005) with some modifications. To achieve this, about $2 \mathrm{~g}$ of each sample was weighed and extracted with $30 \mathrm{~mL} 0.8 \%$ metaphosphoric acid. The liquid extract was centrifuged at $10,000 \mathrm{rpm}$. The supernatant was filtered and diluted with $10 \mathrm{~mL}$ of $0.8 \%$ metaphosphoric acid using $0.45 \mu \mathrm{L}$ filter and $20 \mu \mathrm{L}$ of the filtrate was injected in HPLC for analysis. Various concentrations of ascorbic acid standards were prepared to make a calibration curve. HPLC analysis was done using Shimadzu UV-VIS detector at a wavelength of $266.0 \mathrm{~nm}$. The mobile phase was $0.8 \%$ metaphosphoric acid with flow rate of $1.2 \mathrm{~mL} /$ minute.

\subsection{Antinutrients Determination}

\subsubsection{Determination of Phytates}

Phytates content was determined using HPLC as described by (Camire, \& Clydesdale. (2006). To achieve this, about $0.5 \mathrm{~g}$ of each sample was extracted with $10 \mathrm{~mL}$ of $3 \% \mathrm{H}_{2} \mathrm{SO}_{4}$ and shaken at the automatic shaker for 45minutes. The contents were filtered and the filtrate was transferred to a boiling water bath to heat for 5 minutes followed by addition of $3 \mathrm{~mL}$ of $\mathrm{FeCl}_{3}$ solution $\left(6 \mathrm{mg}\right.$ ferric iron per $\mathrm{mL}$ in $3 \% \mathrm{H}_{2} \mathrm{SO}_{4}$ ). The contents were then heated for 45 minutes to complete precipitation of the ferric phytate complex. Samples were then centrifuged at $2500 \mathrm{rpm}$ for 10 minutes and the supernatant was discarded. The precipitate was washed with 30 $\mathrm{mL}$ of distilled water, centrifuged and the supernatant was discarded. A $3 \mathrm{~mL}$ of $1.5 \mathrm{~N} \mathrm{NaOH}$ was added to the residues and the volumes were brought to $30 \mathrm{~mL}$ with distilled water. The contents were then heated for 30 minutes in a boiling water bath to precipitate the ferric hydroxide. Samples were then cooled and centrifuged and the supernatant was transferred into a $50 \mathrm{~mL}$ volumetric flask. The precipitate was rinsed with $10 \mathrm{~mL}$ distilled water, centrifuged and the supernatant was added to the contents of the volumetric flask. This was filtered using $0.45 \mu \mathrm{L}$ filter before HPLC analysis. The mobile phase was $0.005 \mathrm{~N}$ sodium acetate in distilled water, at a flow rate of $0.5 \mu \mathrm{L} /$ minute.

\subsubsection{Determination of Oxalates}

Oxalic acid contents of the vegetable samples was determined by HPLC method as described by (Chong, Y., Liu, Y., \& Yanping, F. (2002). To achieve this, about $0.3 \mathrm{~g}$ of each sample was homogenized in $10 \mathrm{~mL}$ of $0.5 \mathrm{~N}$ HCL. The homogenate was heated at $80{ }^{\circ} \mathrm{C}$ for 10 minutes with intermittent shaking on the water bath. To the homogenate, distilled water was added up to a volume of $25 \mathrm{~mL}$. About $3 \mathrm{~mL}$ of the solution was withdrawn and centrifuged at 12,000 rpm for 10 minutes. About $1 \mathrm{ml}$ of supernatant was passed through a micro filter $(0.45 \mu \mathrm{L})$ before HPLC analysis. Phytic acid standards were prepared at varying concentrations for quantification. HPLC analysis was done by UV-VIS detector using a solution of $0.01 \mathrm{~N} \mathrm{H}_{2} \mathrm{SO}_{4}$ as mobile phase. The flow rate was 0.6 $\mathrm{mL} /$ minute and was detected at a wavelength length of $221 \mathrm{~nm}$.

\subsubsection{Determination of Tannins}

Tannins were estimated by Vanillin- $\mathrm{HCl}$ method as described by Millet P, (2013). Approximately $0.1 \mathrm{~g}$ of ground dry leaf vegetable samples were accurately weighed into Erlenmeyer flasks. $10 \mathrm{ml}$ of $4 \%$ HCL in methanol was pipetted into each flask, sealed with parafilm and shaken (KS 250 basic, Germany) for 20 minutes, centrifuged (HPLC-CTO-10AVP Shimadzu; detector used- Shimadzu RID6A Refractive Index Detector) for 10 minutes at $4500 \mathrm{rpm}$ and supernatants were transferred to $25 \mathrm{ml}$ volumetric flasks. The residues were extracted for the second time using $5 \mathrm{ml}$ of $1 \% \mathrm{HCL}$ in methanol for 10 minutes. The aliquots of the first and the second extracts were combined and made up to $25 \mathrm{ml}$ volume using methanol. A set of catechin (Sigma) standards solutions were prepared ranging from 10 to $100 \mathrm{ppm}$ using methanol as a solvent. One $(1 \mathrm{ml})$ of suitably diluted extracts were taken in a test tube and $5 \mathrm{ml}$ of freshly prepared vanillin- $\mathrm{HCl}$ reagent was added to each test tube. To correct for interference of natural pigments in the dry vegetables, a blank sample was prepared by subjecting the original extract to the reaction conditions without the vanillin reagent. These were prepared by adding $5 \mathrm{ml}$ of $4 \% \mathrm{HCL}$ in methanol to $1 \mathrm{ml}$ of the aliquots of the extracts that were pipetted into the test tubes. The absorbances of the standard solutions, sample extracts and blanks were read using a UV-VIS Spectrophotometer (Shimadzu, UV mini 1240, Japan) at $500 \mathrm{~nm}$ exactly 20 minutes after adding Vanillin-HCL reagent to the samples and standards. A standard curve was prepared from the readings of the catechin standard solutions. Tannin content was expressed in $\mathrm{mg}$ of catechin equivalent (CE) per $100 \mathrm{~g}$ of sample $(\mathrm{mg} \mathrm{CE} / 100 \mathrm{~g})$.

\subsection{Data Analysis}

Data was analysed using STATA software (STATA 14.0, 2015, Texas, USA). The mean differences for nutrients and antinutrients within the sample groups as affected by treatments was tested for its significance differences 
using one way analysis of variance (ANOVA) by Bonferroni test. A p-value of $\leq 0.05$ was used for the test of significance. All samples were analyzed in triplicates.

\section{Results and Discussion}

\subsection{Effects of Wet Frying and Boiling on Nutrients Content}

\subsubsection{Effects of Wet Frying and Boiling on Crude Fats}

The results for Crude fats in the five traditional vegetables and its respective wet fried and boiled counterparts for each vegetable are presented in Table 1 . The percentages of crude fats in the dry uncooked vegetables ranged from $1.07 \%$ to $2.28 \%$. The mean amount of crude fats in the five vegetables were $2.28 \%, 2.18 \%, 1.91 \%, 1.32 \%$ and $1.07 \%$ in Moringa oleifera, black jack, sweet potato leaves, jute mallow and Amaranth hybridus respectively.

Table 1. Crude fat content (\%) in traditional vegetables as influenced by cooking methods

\begin{tabular}{|c|c|c|c|}
\hline Vegetable leaves & Dried $(n=3)$ & Wet fried $(n=3)$ & Boiled $(n=3)$ \\
\hline Sweet potato & $1.91 \pm 0.06^{\mathrm{b}}$ & $30.31 \pm 0.46^{\mathrm{a}}$ & $2.82 \pm 0.13^{\mathrm{b}}$ \\
\hline Black jack & $2.18 \pm 0.45^{\mathrm{b}}$ & $31.61 \pm 1.47^{\mathrm{a}}$ & $2.70 \pm 0.35^{\mathrm{b}}$ \\
\hline Moringa oleifera & $2.28 \pm 0.48^{\mathrm{b}}$ & $19.00 \pm 0.26^{\mathrm{a}}$ & $1.81 \pm 0.17^{\mathrm{b}}$ \\
\hline Jute mallow & $1.32 \pm 0.62^{\mathrm{b}}$ & $16.81 .1 .31^{\mathrm{a}}$ & $2.42 \pm 0.33^{\mathrm{b}}$ \\
\hline Amaranth hybridus & $1.07 \pm 0.40^{\mathrm{b}}$ & $28.07 \pm 2.53^{\mathrm{a}}$ & $1.68 \pm 1.06^{\mathrm{b}}$ \\
\hline
\end{tabular}

Entries are Mean $\pm \mathrm{SD}$

Values in the same row followed by the same superscripts are not significantly different at $\alpha=0.05$ using Bonferroni ANOVA test.

There was no significant difference in the percentage of fats between the boiled vegetables and the raw vegetables. Wet frying significantly increased $(P \geq 0.05)$ the amount of fats in all the vegetables. The increase of fats in the wet fried samples is due to absorption of fats by the vegetables during the process of wet frying. The percentages of fats in the wet fried vegetables ranged from $16.81 \%$ to $30.31 \%$. The differences in the percentage of absorbed fats in the wet fried vegetables might be due to different matrix of the vegetable leaves.

\subsubsection{Effect of Boiling and Wet Frying on Ash Content}

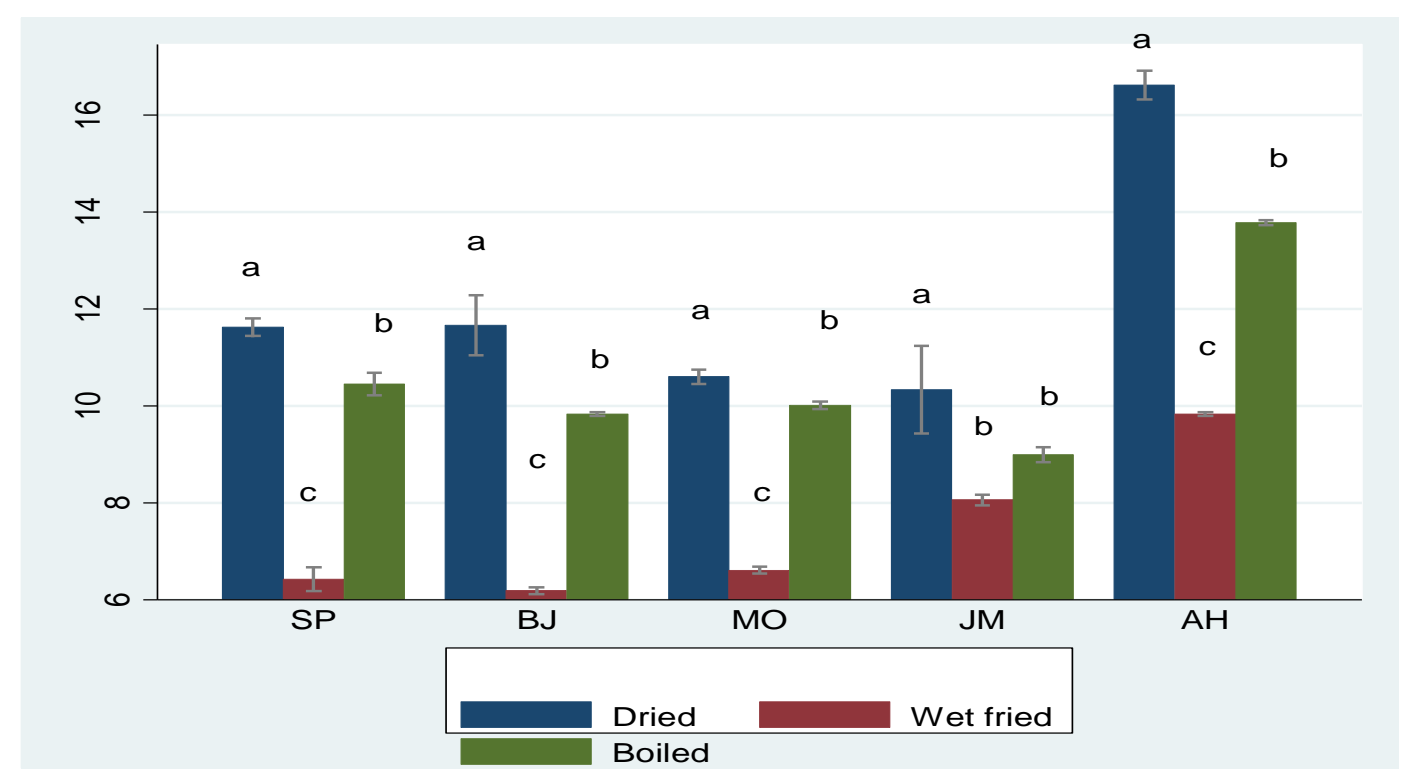

Figure 1 . Mean $\%$ of ash in traditional vegetables as influenced by cooking methods. $\mathrm{SP}=\mathrm{Sweet}$ potato; $\mathrm{BJ}=$

Black jack; $\mathrm{MO}=$ Moringa oleifera; $\mathrm{JM}=$ Jute mallow and $\mathrm{AH}=$ Amaranthus hybridus. Mean $\pm \mathrm{SD}$ values $(\mathrm{n}=3)$ in the same group followed by the same superscripts are not significantly different at $(\mathrm{p} \leq 0.05)$ using Bonferroni 
The ash content in the dry uncooked vegetables ranged from $10.33 \%$ to $16.61 \%$. The ash content in these dry uncooked vegetables were $16.61 \%, 11.67 \%, 11.62 \%, 10.60 \%, 10.33 \%$ and in the leaves of Amaranth hybridus, black jack, sweet potato, Moringa oleifera and jute mallow respectively. Figure 1 indicate that there were significant differences in the percentages of ash as a result of wet frying and boiling in all the vegetables. Wet frying resulted to higher losses of ash in all the vegetables compared to boiling except in jute mallow vegetables where the ash reduction was statistically similar $(\mathrm{P} \geq 0.05)$ for wet fried and boiled jute mallow. The higher reduction of ash percentages in wet fried as compared to boiled vegetables is as a result of high absorption of oils in the wet fried vegetables that led to apparent decrease in percentages of ash. The loss of ash due to boiling could be as a result of leaching of minerals in the boiling water. Thus most minerals were leached into the boiling water and this led to reduced ash content because the ash contains minerals. These results tally with the work done by Traoré, K., Parkouda, C., Savadogo, A., Ba, F., Regine, H., \& Yves, K., (2017) where it was found that the amount of ash reduced after blanching and boiling of vegetables that included jute mallow and Amaranth cruentus $L$. The authors found that the amount of ash reduced in jute mallow and Amaranth from $12.40 \%$ and $16.33 \%$ to $9.37 \%$ and $14.27 \%$ respectively after boiling for 30 minutes due to leaching of minerals in the boiling water.

In this study, the percentage of ash in jute mallow and Amaranthus hybridus reduced from $10.60 \%$ and $16.61 \%$ to $8.06 \%$ and $9.83 \%$ after wet frying; and to $8.99 \%$ and $13.78 \%$ after boiling them respectively. The apparent reduction of percentages of ash in the wet fried vegetables is due to increased oil content. Gunathilake, K. D. P. P., Ranaweera, K. K. D. S., \& Rupasinghe, H. P. V., (2018) reported that during deep-fat frying, oils undergo physicochemical changes; the food dehydrates, and oils penetrates the food.

\subsubsection{Effect of Boiling and Wet Frying on Iron Content}

Figure 2 presents the iron content of the five traditional leafy vegetables; sweet potato, black jack, Moringa oleifera, jute mallow and Amaranthus hybridus. It also presents the amount of iron in the vegetables as influenced by wet frying and boiling of each of the traditional vegetables. The amount of iron in the dry uncooked vegetables ranged from $37.22 \mathrm{mg} / 100 \mathrm{~g}$ to $48.21 \mathrm{mg} / 100 \mathrm{~g}$ on dry wet basis. The iron content in the dry uncooked vegetables were $48.21 \mathrm{mg} / 100 \mathrm{~g}, 40.43 \mathrm{mg} / 100 \mathrm{~g}, 37.22 \mathrm{mg} / 100 \mathrm{~g}, 37.30 \mathrm{mg} / 100 \mathrm{~g}$ and $44.89 \mathrm{mg} / 100 \mathrm{~g}$ in the leaves of sweet potato, black jack, Moringa oleifera, jute mallow and Amaranth hybridus respectively. Boiling and wet frying for 10 minutes did not significantly reduce $(\mathrm{P} \geq 0.05)$ iron content in black jack leaves although there was some slight losses of iron due to these processes. There were significant losses $(\mathrm{P} \leq 0.05)$ of iron in sweet potato leaves, Moringa oleifera leaves and jute mallow leaves as a result of wet frying and boiling. Wet frying significantly $(\mathrm{P} \leq 0.05)$ reduced iron content in Moringa oleifera and jute mallow vegetables as compared to boiling the same vegetables for 10 minutes. The losses of iron due to boiling is as a result of leaching of the mineral iron into the boiling water. These results are similar to work done by Lewu, M. N., Adebola, P. O., \& Afolayan, A. J. (2009) where the authors found that there were losses of iron due to boiling in most of the vegetables. Habwe, F. O., Walingo, M. K., Abukutsa-onyango, M. O., \& Oluoch, M. O. (2009) also found a high reduction of iron content as a result of wet frying as compared to boiling for 5 minutes in Amaranthus hybridus. However, Ojo, O. O., Taiwo, K. A., Scalon, M., Oyedele, D. J., \& Akinremi, O. O. (2016) reported slight increase of iron in Solanum marcrocarpon after boiling for 5 minutes in seven cultivars. 


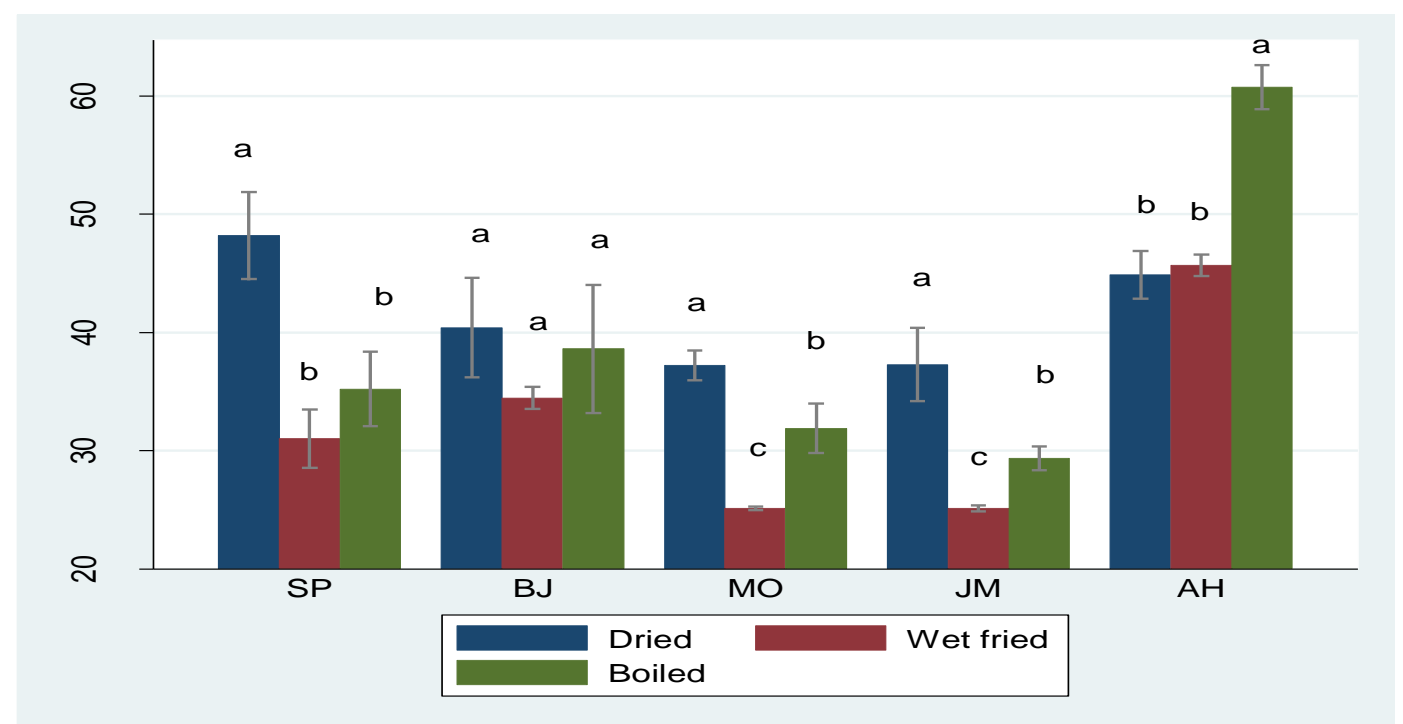

Figure 2. Mean amount of iron in traditional vegetables as influenced by cooking methods. SP=sweet potato, $\mathrm{BJ}=$ Black jack, $\mathrm{MO}=$ Moringa oleifera, $\mathrm{JM}=\mathrm{Jute}$ mallow and $\mathrm{AH}=$ Amaranthus hybridus. Mean $\pm \mathrm{SD}$ values in the same group followed by the same superscripts are not significantly different at $(\mathrm{p} \leq 0.05)$ using Bonferroni

ANOVA test

\subsubsection{Effect of Boiling and Wet Frying on Zinc Content}

The results for Zinc content of the five traditional vegetables and its respective wet fried and boiled counterparts for each vegetable are presented in Table 2 . The amount of zinc in the dry uncooked vegetables ranged from $4.42 \mathrm{mg} / 100 \mathrm{~g}$ to $10.59 \mathrm{mg} / 100 \mathrm{~g}$ on dry weight basis. The mean amount of zinc in these vegetables were $5.47 \mathrm{mg} / 100 \mathrm{~g}, 7.27 \mathrm{mg} / 100 \mathrm{~g}, 10.59 \mathrm{mg} / 100 \mathrm{~g}, 4.42 \mathrm{mg} / 100 \mathrm{~g}$ and $5.70 \mathrm{mg} / 100 \mathrm{~g}$ in the leaves of sweet potato, black jack, Moringa oleifera, jute mallow and Amaranth hybridus respectively. There was a significant reduction $(\mathrm{P} \leq 0.05)$ of zinc in sweet potato leaves, Moringa oleifera leaves, and Jute mallow due to wet frying and boiling for 10 minutes. Boiling of vegetables was also reported to reduce amount of zinc in different cultivars of Colocasia esculenta vegetables (Lewu et al., 2009). Boiling did not significantly reduce the amount of zinc in black jack leaves, however, wet frying reduced the zinc concentration significantly $(\mathrm{P} \leq 0.05)$. Wet frying also decreased the amount of zinc in Jute mallow significantly $(\mathrm{P} \leq 0.05)$ compared to boiling the same vegetables for 10 minutes due to apparent increase in fats. There was also a significant reduction of zinc in Amaranthus hybridus due to wet frying as compared to boiling.

Table 2. Zinc content ( $\mathrm{mg} / 100 \mathrm{~g} \mathrm{DM})$ in traditional vegetables as influenced by cooking methods

\begin{tabular}{llll}
\hline Vegetable leaves & Dried $(\mathbf{n}=\mathbf{3})$ & Wet fried $(\mathbf{n}=\mathbf{3})$ & Boiled $(\mathbf{n}=\mathbf{3})$ \\
\hline Sweet potato & $5.47 \pm 2.38^{\mathrm{a}}$ & $2.43 \pm 0.70^{\mathrm{b}}$ & $6.15 \pm 0.87^{\mathrm{b}}$ \\
Black jack & $7.27 \pm 0.98^{\mathrm{a}}$ & $4.82 \pm 0.64^{\mathrm{b}}$ & $6.49 \pm 0.16^{\mathrm{a}}$ \\
Moringa oleifera & $10.59 \pm 2.32^{\mathrm{a}}$ & $1.78 \pm 0.04^{\mathrm{b}}$ & $2.48 \pm 0.03^{\mathrm{b}}$ \\
Jute mallow & $4.42 \pm 0.12^{\mathrm{a}}$ & $2.37 \pm 0.05^{\mathrm{c}}$ & $3.01 \pm 0.07^{\mathrm{b}}$ \\
Amaranth hybridus & $5.70 \pm 0.20^{\mathrm{b}}$ & $4.73 \pm 0.12^{\mathrm{c}}$ & $9.03 \pm 0.20^{\mathrm{a}}$ \\
\hline
\end{tabular}

Entries are mean $\pm \mathrm{SD}$

Values in the same row followed by the same superscripts are not significantly different at $\alpha=0.05$ using Bonferroni ANOVA test.

\subsubsection{Effect of Boiling and Wet Frying on Copper Content}

Figure 3 presents the results for amount of Copper in the raw dried vegetables and their respective wet fried and boiled vegetables. The amount of Copper in the raw dried vegetables ranged from $1.29 \mathrm{mg} / 100 \mathrm{~g}$ to $3.90 \mathrm{mg} / 100 \mathrm{~g}$. The mean amount of Copper in the vegetables were $1.29 \mathrm{mg} / 100 \mathrm{~g}, 1.55 \mathrm{mg} / 100 \mathrm{~g}, 1.98 \mathrm{mg} / 100 \mathrm{~g}, 3.20 \mathrm{mg} / 100 \mathrm{~g}$ and $3.90 \mathrm{mg} / 100 \mathrm{~g}$ in Moringa oleifera, Amaranth hybridus, jute mallow, sweet potato leaves and black jack respectively. The results indicate that there was no significant loss $(\mathrm{P} \leq 0.05)$ of copper due to boiling of sweet 
potato leaves, black jack leaves and jute mallow leaves. There was however significant decrease $(\mathrm{P} \leq 0.05)$ of copper due to wet frying in sweet potato leaves, black jack leaves, and jute mallow leaves because these vegetables absorbed higher oils. There was no significant loss of copper due to wet frying in Moringa oleifera leaves because Moringa oleifera absorbed relatively less amount of oils that resulted to apparent less effect on copper content. Lewu et al., 2009 reported good retention of copper after boiling in several cultivars of Colocasia esculenta with little or no losses of the mineral in other cultivars. Ojo et al., (2016) also reported slight reduction of copper in Solanum marcrocarpon after boiling for 5 minutes.

\subsubsection{Effect of Boiling and Wet Frying on Calcium Content}

The results for amount of Calcium in the five vegetables and its respective wet fried and boiled counterparts for each vegetable are presented in Figure 4. The amount of Calcium in the uncooked dried vegetables ranged from $150.86 \mathrm{mg} / 100 \mathrm{~g}$ to $559.75 \mathrm{mg} / 100 \mathrm{~g}$. The mean amount of Calcium in the leafy vegetables were $150.86 \mathrm{mg} / 100 \mathrm{~g}$, $176.54 \mathrm{mg} / 100 \mathrm{~g}, 242.95 \mathrm{mg} / 100 \mathrm{~g}, 396.10 \mathrm{mg} / 100 \mathrm{~g}$ and $559.75 \mathrm{mg} / 100 \mathrm{~g}$ in black jack , jute mallow, sweet potato leaves, Amaranth hybridus and Moringa oleifera respectively. There were significant losses $(\mathrm{P} \leq 0.05)$ of calcium due to wet frying in the vegetable leaves of sweet potato, black jack, Moringa oleifera and Amaranthus hybridus due to apparent increase in crude fats. There was no significant loss of calcium as a result of boiling in black jack, Moringa oleifera, jute mallow and Amaranthus hybridus leafy vegetables due to possible insolubility of calcium in these vegetables. In a study by Ojo et al., 2016, it was found that boiling retained the amount of Calcium after boiling Solanum marcrocarpon for five minutes. Wet frying did not significantly reduce calcium content in jute mallow leafy vegetables.

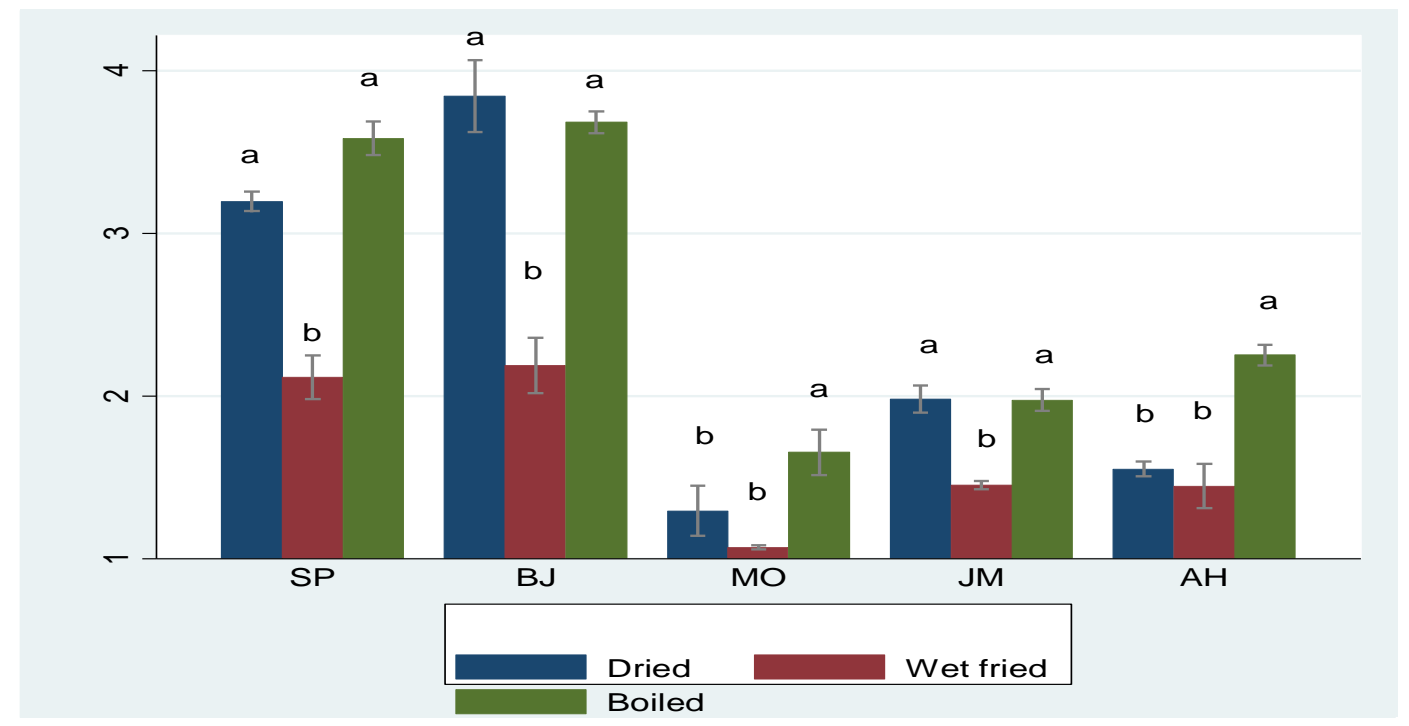

Figure 3. Mean amount of Copper in traditional vegetables as influenced by cooking methods. $\mathrm{SP}=$ sweet potato, $\mathrm{BJ}=\mathrm{Black}$ jack, $\mathrm{MO}=$ Moringa oleifera, $\mathrm{JM}=\mathrm{Jute}$ mallow and $\mathrm{AH}=$ Amaranthus hybridus. Mean $\pm \mathrm{SD}$ values in the same group followed by the same superscripts are not significantly different at $\alpha=0.05$ using Bonferroni 


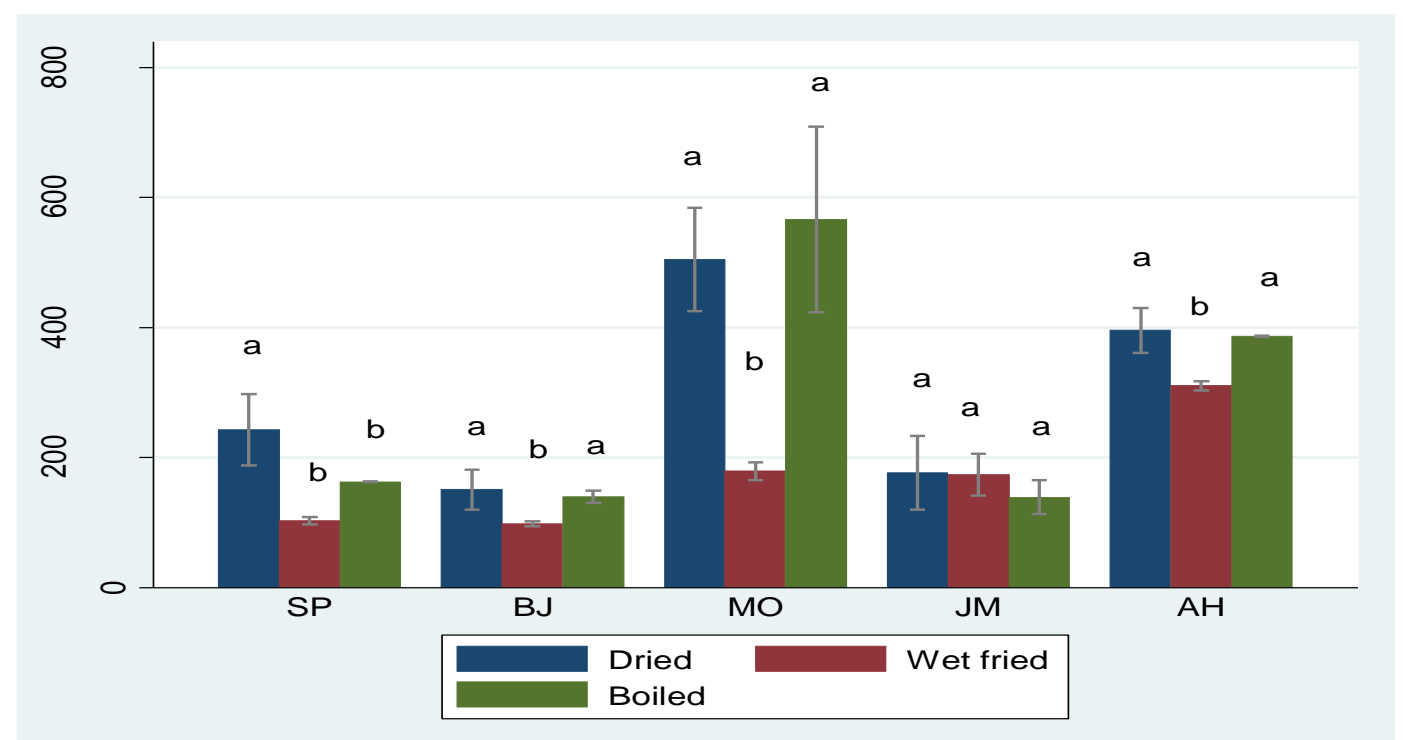

Figure 4. Mean amount of Calcium in traditional vegetables as influenced by cooking methods. SP=sweet potato, $\mathrm{BJ}=\mathrm{Black}$ jack, $\mathrm{MO}=$ Moringa oleifer, $\mathrm{JM}=\mathrm{Jute}$ mallow and $\mathrm{AH}=$ Amaranthus hybridus. Mean $\pm \mathrm{SD}$ values in the same group followed by the same superscripts are not significantly different at $\alpha=0.05$ using Bonferroni ANOVA test

\subsubsection{Effect of Boiling and Wet Frying on Magnesium Content}

Magnesium content of the five traditional leafy vegetables and their respective boiled and wet fried counterparts are presented in table 3. The amount of Magnesium in the uncooked dry vegetables ranged from $101.19 \mathrm{mg} / 100 \mathrm{~g}$ to $196.22 \mathrm{mg} / 100 \mathrm{~g}$. The mean amount of Magnesium in the leafy vegetables were $101.19 \mathrm{mg} / 100 \mathrm{~g}$, $142.23 \mathrm{mg} / 100 \mathrm{~g}, 154.67 \mathrm{mg} / 100 \mathrm{~g}, 156.07 \mathrm{mg} / 100 \mathrm{~g}$ and $196.22 \mathrm{mg} / 100 \mathrm{~g}$ in jute mallow, black jack, Moringa oleifera, sweet potato leaves and Amaranth hybridus respectively. There were significant losses $(\mathrm{P} \leq 0.05)$ of Magnesium due to wet frying in leafy vegetables of sweet potato, black jack, Moringa oleifera, and Amaranth hybridus. Boiling significantly $(\mathrm{P} \leq 0.05)$ reduced the amount of Magnesium in sweet potato leaves but not as much as wet frying. There was no significant loss of Magnesium as a result of boiling in the vegetable leaves of black jack, Moringa oleifera, jute mallow and Amaranthus hybridus. Lewu et al., 2009 however reported slight reduction of Magnesium in some cultivars of Colocasia esculenta after boiling for five minutes. The reduction of Magnesium in the vegetables as a result of boiling is due to leaching of the mineral in the boiling water.

Table 3. Magnesium content $(\mathrm{mg} / 100 \mathrm{~g})$ in traditional vegetables as influenced by cooking methods

\begin{tabular}{llll}
\hline Vegetable leaves & Dried $(\mathbf{n}=\mathbf{3})$ & Wet fried $(\mathbf{n}=\mathbf{3})$ & Boiled $(\mathbf{n}=\mathbf{3})$ \\
\hline Sweet potato & $156.07 \pm 2.49^{\mathrm{a}}$ & $93.47 \pm 2.34^{\mathrm{c}}$ & $134.83 \pm 5.45^{\mathrm{b}}$ \\
Black jack & $142.23 \pm 2.09^{\mathrm{a}}$ & $101.37 \pm 5.08^{\mathrm{b}}$ & $146.89 \pm 5.01^{\mathrm{a}}$ \\
Moringa oleifera & $154.67 \pm 4.40^{\mathrm{b}}$ & $148.25 \pm 4.91^{\mathrm{b}}$ & $179.61 \pm 5.85^{\mathrm{a}}$ \\
Jute mallow & $101.19 \pm 5.77^{\mathrm{a}}$ & $93.99 \pm 1.33^{\mathrm{a}}$ & $106.47 \pm 1.17^{\mathrm{a}}$ \\
Amaranth hybridus & $196.22 \pm 0.60^{\mathrm{a}}$ & $189.45 \pm 1.59^{\mathrm{b}}$ & $196.96 \pm 3.18^{\mathrm{a}}$ \\
\hline
\end{tabular}

Entries are Mean $\pm \mathrm{SD}$

Values in the same row followed by the same superscripts are not significantly different at $\alpha=0.05$ using Bonferroni ANOVA test.

\subsubsection{Effect of Boiling and Wet Frying on Beta-carotene Content}

Figure 5 presents the results for mean amount of beta-carotene in the five traditional vegetables and the influence of 10 minutes wet frying and boiling for each of the vegetables on beta-carotene. The amount of beta-carotene in the uncooked dried vegetables ranged from $829.68 \mu \mathrm{g} / 100 \mathrm{~g}$ to $5791.64 \mu \mathrm{g} / 100 \mathrm{~g}$ on dry weight basis. The mean amount of beta-carotene in the leafy vegetables were $5791.64 \mu \mathrm{g} / 100 \mathrm{~g}, 2153.29 \mu \mathrm{g} / 100 \mathrm{~g}, 1242.21 \mu \mathrm{g} / 100 \mathrm{~g}$, $1055 \mu \mathrm{g} / 100 \mathrm{~g}$ and $829.68 \mu \mathrm{g} / 100 \mathrm{~g}$ in Moringa oleifera, jute mallow, black jack, sweet potato leaves and Amaranth hybridus respectively. Boiling did not significantly reduce $(\mathrm{P} \leq 0.05)$ beta-carotene content in the 
vegetables leaves of sweet potato, black jack and Moringa oleifera. There was however better retention of beta-carotene in sweet potato and black jack leaves as a result of boiling. Wet frying significantly reduced beta-carotene content in black jack leafy vegetables. There was no significant loss $(\mathrm{P} \leq 0.05)$ of beta-carotene in Amaranthus hybridus due to wet frying, however, boiling retained the vitamin significantly in the same vegetable. There was also a significant retention of $(\mathrm{P} \geq 0.05)$ beta-carotene due to boiling for 10 minutes in jute mallow vegetables. These results agrees with the work by Ogliano, V. I. F., \& Ellegrini, N. I. P. (2008) where they found that in most vegetables frying reduced the amount of beta-carotene and boiling for a short period increased beta-carotene in broccoli and courgettes vegetables. Cooking of green fresh vegetables has been reported to promote release of carotenoids from the matrix because of the disruption of carotenoids-protein complexes, leading to better extractability and higher concentrations in cooked samples (Ogliano et al., 2008). Beta-carotene losses due to frying has been attributed to loss of the initial carotenoids concentration because of leaching into oil at higher processing temperature. Traoré et al., 2017 also reported a reduction of beta-carotene in jute mallow and amaranth due to shade drying alone. The results for shade dried samples of jute mallow and amaranth in this study agrees with those reported by Traore et al., 2017. Results from the study by Putra, U. (2009) showed that both boiling and stir-frying increased the beta-carotene (2 to 4.2 times) of pumpkin. It was found that boiling for 4 minutes resulted in the highest (4.2 times) increase of beta-carotene to $8.0 \mathrm{mg} / 100 \mathrm{~g}$ from $2.0 \mathrm{mg} / 100 \mathrm{~g}$. Six minutes boiling, on the other hand, resulted in $270 \%$ (3.7 times) increase in beta-carotene content. In this study all the vegetables were either wet fried or boiled for 10 minutes. The 10 minutes cooking in this study may attribute to more losses of beta-carotene as compared to when they would be cooked at a shorter period. Long time cooking is attributed to longer exposure to oxidation and heat thereby leading to more losses of beta-carotene. The higher losses of beta-carotene due to wet frying compared to boiling at 10 minutes in this study might be attributed to the fact that carotenoids are fat-soluble compounds and solubilized readily in oil during stir-frying as explained by Putra, 2009.

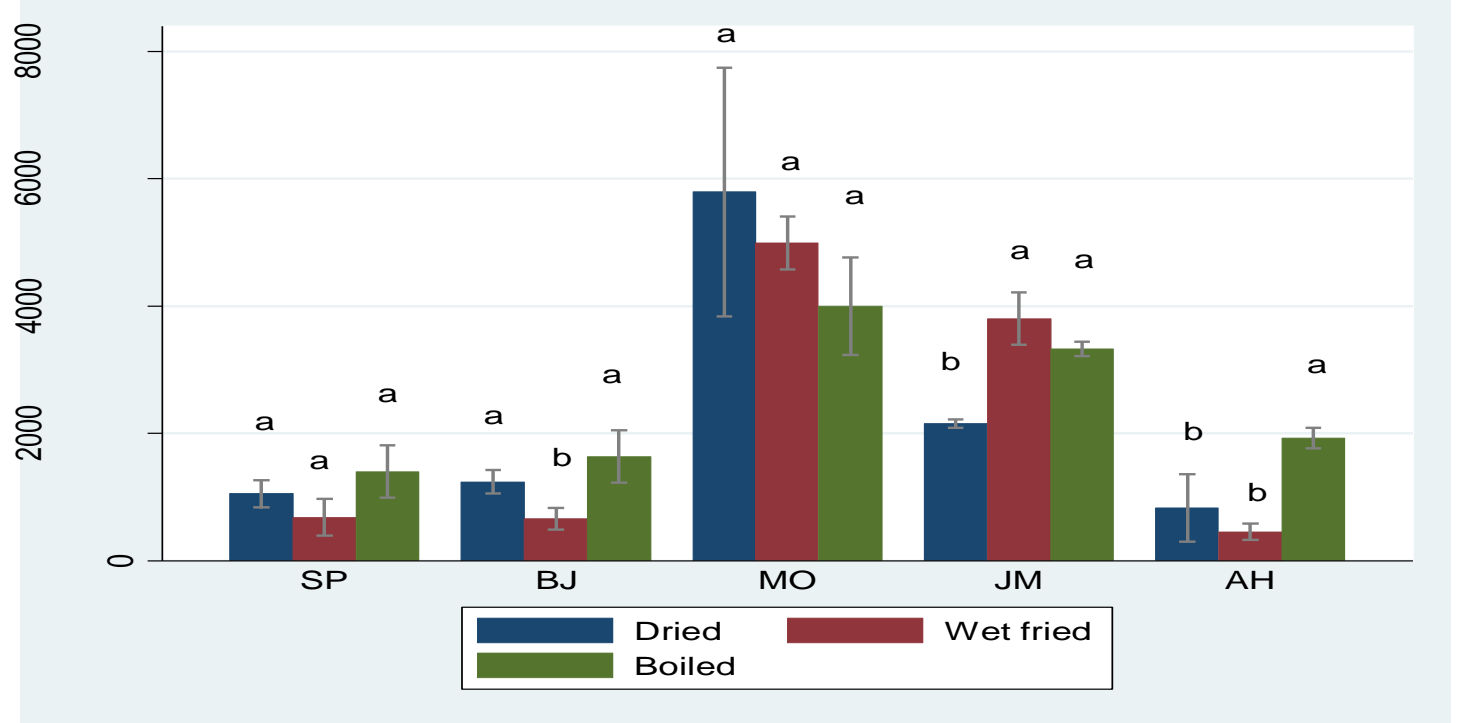

Figure 5. Mean amount of beta-carotene in traditional vegetables as influenced by cooking methods. $\mathrm{SP}=\mathrm{sweet}$ potato, $\mathrm{BJ}=\mathrm{Black}$ jack, $\mathrm{MO}=$ Moringa oleifera, $\mathrm{JM}=$ Jute mallow and $\mathrm{AH}=$ Amaranthus hybridus. Mean $\pm \mathrm{SD}$ values in the same group followed by the same superscripts are not significantly different at $\alpha=0.05$ using Bonferroni ANOVA test

\subsubsection{Effect of Boiling and Wet Frying on Vitamin C (Ascorbic acid) Content}

The results for Vitamin $\mathrm{C}$ content of the five traditional vegetables and its respective wet fried and boiled counterparts for each vegetable are presented in Figure 6. The amount of ascorbic acid in the uncooked dry vegetables ranged from $7.93 \mathrm{mg} / 100 \mathrm{~g}$ to $35.81 \mathrm{mg} / 100 \mathrm{~g}$ on dry weight basis. The mean amount of beta-carotene in the leafy vegetables were $35.81 \mathrm{mg} / 100 \mathrm{~g}, 28.78 \mathrm{mg} / 100 \mathrm{~g}, 25.48 \mathrm{mg} / 100 \mathrm{~g}, 22.85 \mathrm{mg} / 100 \mathrm{~g}$ and $7.93 \mathrm{mg} / 100 \mathrm{~g}$ in the leaves of sweet potatoes, black jack, Moringa oleifera, jute mallow and Amaranth hybridus respectively. Boiling significantly reduced $(\mathrm{P} \leq 0.05)$ vitamin $\mathrm{C}$ content in all the vegetables except in Amaranthus hybridus where the amount of vitamin $C$ was slightly reduced. Wet frying significantly retained $(P \geq 0.05)$ vitamin $C$ in all the five traditional vegetables. The vitamin $\mathrm{C}$ losses in the vegetables due to boiling might be attributed to 
leaching of the vitamin in the boiling water because Vitamin C is water soluble. Singh \& Harshal, 2016 reported losses of Vitamin $\mathrm{C}$ content in several vegetables after boiling for 10 minutes and after blanching and microwaving. In their study, microwaving the vegetables significantly reduced the amount of Vitamin $C$ than blanching and boiling. The high retention of vitamin $\mathrm{C}$ due to wet frying in the wet fried samples in this study might be due to its preservation in the cooking oil because vitamin $\mathrm{C}$ is slightly soluble in oil. There were slight higher vitamin $\mathrm{C}$ content in almost all the wet fried vegetables compared to uncooked dried vegetables because the wet fried vegetables were dried alongside the uncooked vegetables and more losses of vitamin $\mathrm{C}$ in uncooked vegetables might occur during drying. The results for wet frying in this study, agrees with Masrizal, M., \& Giraud, D. (1996) where it was found that stir frying in cooking oil had the highest retention (by 1.31-1.83 fold) of vitamin C in several vegetables than boiling. Armesto, J., Gómez-limia, L., Carballo, J., Martínez, S., Armesto, J., Gómez-limia, L., ... Armesto, J. (2019) also reported significant losses of vitamin C in Brassica oleracea after boiling for 20 and 30 minutes.

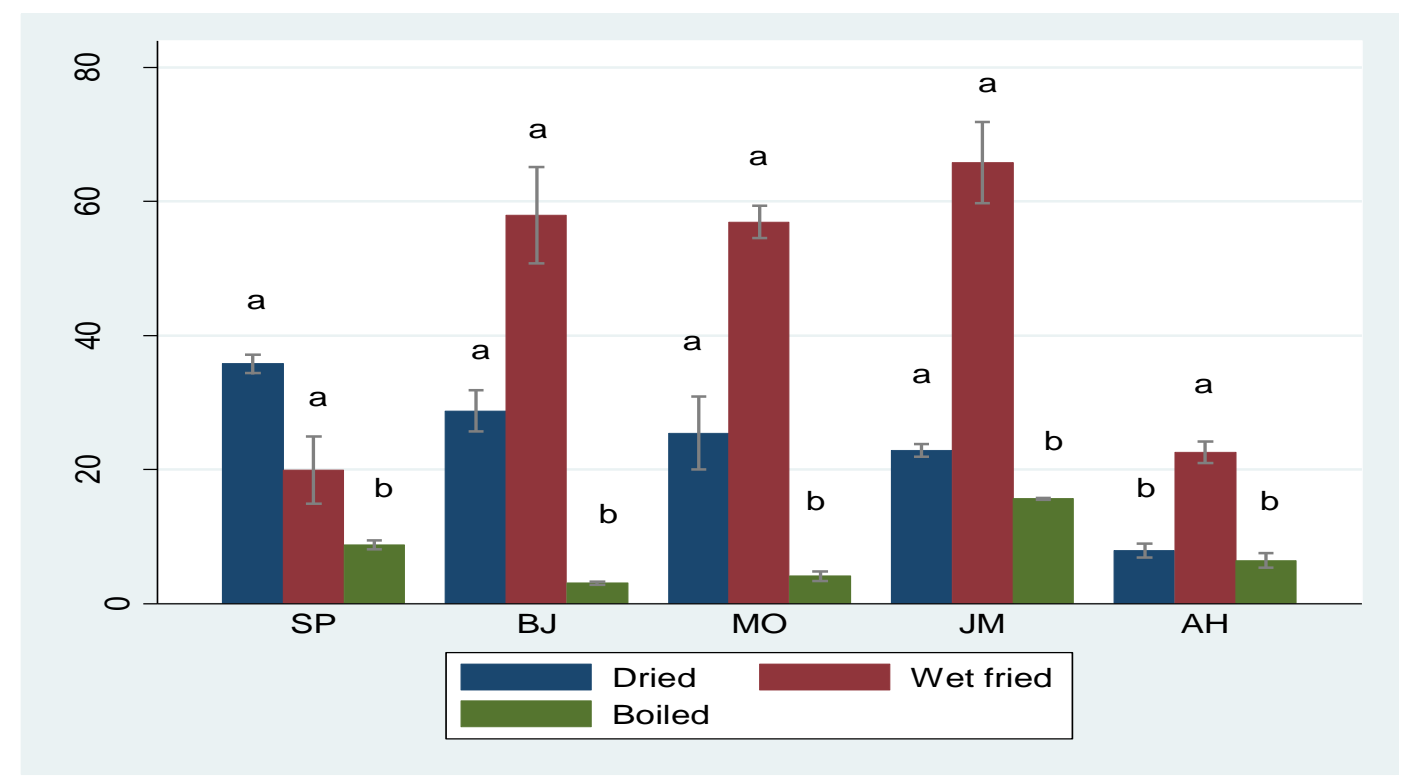

Figure 6. Mean amount of ascorbic acid in traditional vegetables as influenced by cooking methods. $\mathrm{SP}=$ sweet potato, $\mathrm{BJ}=\mathrm{Black}$ jack, $\mathrm{MO}=$ Moringa oleifer, $\mathrm{JM}=\mathrm{Jute}$ mallow and $\mathrm{AH}=$ Amaranthus hybridus. Mean $\pm \mathrm{SD}$ values in the same group followed by the same superscripts are not significantly different at $\alpha=0.05$ using

Bonferroni ANOVA test

\subsection{Effects of Wet Frying and Boiling on Anti-nutrients}

\subsubsection{Effects of Wet Frying and Boiling on Oxalates}

The results for oxalates in the five traditional vegetables and its respective wet fried and boiled counterparts for each vegetable are presented in figure 7 . The amount of oxalates in the uncooked dry vegetables ranged from $77.06 \mathrm{mg} / 100 \mathrm{~g}$ to $771.95 \mathrm{mg} / 100 \mathrm{~g}$ on dry weight basis. The mean amount of oxalates in these uncooked vegetables were $77.06 \mathrm{mg} / 100 \mathrm{~g}, 276.07 \mathrm{mg} / 100 \mathrm{~g}, 286.73 \mathrm{mg} / 100 \mathrm{~g}, 306.95 \mathrm{mg} / 100 \mathrm{~g}$ and $771.95 \mathrm{mg} / 100 \mathrm{~g}$ in black jack, jute mallow, sweet potato leaves, Moringa oleifera and Amaranth hybridus respectively. Both boiling and wet frying significantly reduced $(\mathrm{P} \leq 0.05)$ amount of oxalates in vegetable leaves of sweet potato, Moringa oleifera, jute mallow and Amaranthus hybridus. Ojo et al., (2016) also reported a reduction of oxalates in Solanum marcrocarpon vegetables after boiling for five minutes. In this study, there was no significant reduction $(\mathrm{P} \geq 0.05)$ of oxalates in black jack leaves. The loss of oxalates in both wet fried and boiled black lack leaves was 17\%. Also, Mcewan, R., Shangase, F. N., Djarova, T., \& Opoku, A. R.,(2014) reported a significant reduction of Oxalates in Colocasia esculenta after boiling as compared to stir frying.

\subsubsection{Effects of Wet Frying and Boiling on Phytates Content}

The results for phytates content in the five traditional vegetables and its respective wet fried and boiled counterparts for each vegetable are presented in Table 4. Phytates content in the uncooked dry vegetables ranged from $72.17 \mathrm{mg} / 100 \mathrm{~g}$ to $129.15 \mathrm{mg} / 100 \mathrm{~g}$ on dry weight basis. The mean amount of phytates in these uncooked 
vegetables were $72.17 \mathrm{mg} / 100 \mathrm{~g}, \quad 86.64 \mathrm{mg} / 100 \mathrm{~g}, \quad 99.80 \mathrm{mg} / 100 \mathrm{~g}, 124.95 \mathrm{mg} / 100 \mathrm{~g}$ and $129.15 \mathrm{mg} / 100 \mathrm{~g}$ in Amaranth hybridus, jute mallow, Moringa oleifera, black jack and sweet potato leaves respectively. Boiling significantly reduced $(\mathrm{P} \leq 0.05)$ the amount of phytates in jute mallow and Amaranthus hybridus vegetables. There were significant losses $(\mathrm{P} \leq 0.05)$ of phytates due to wet frying in Moringa oleifera and jute mallow vegetables. There were slight losses of phytates in both wet fried and boiled sweet potato and black jack leafy vegetables though not significant $(\mathrm{P} \geq 0.05)$. Wet frying reduced the amount of phytates in Amaranthus hybridus and black jack vegetables by $47 \%$ and 32\% respectively. Results by Mcewan et al., (2014) revealed a significant reduction of phytates after boiling and stir frying, where stir frying reduced the phytates more than boiling for the same period in the tubers of Colocasia esculenta. The losses of phytates due to wet frying and boiling might be as a result of thermal degradation and dissolution in water.

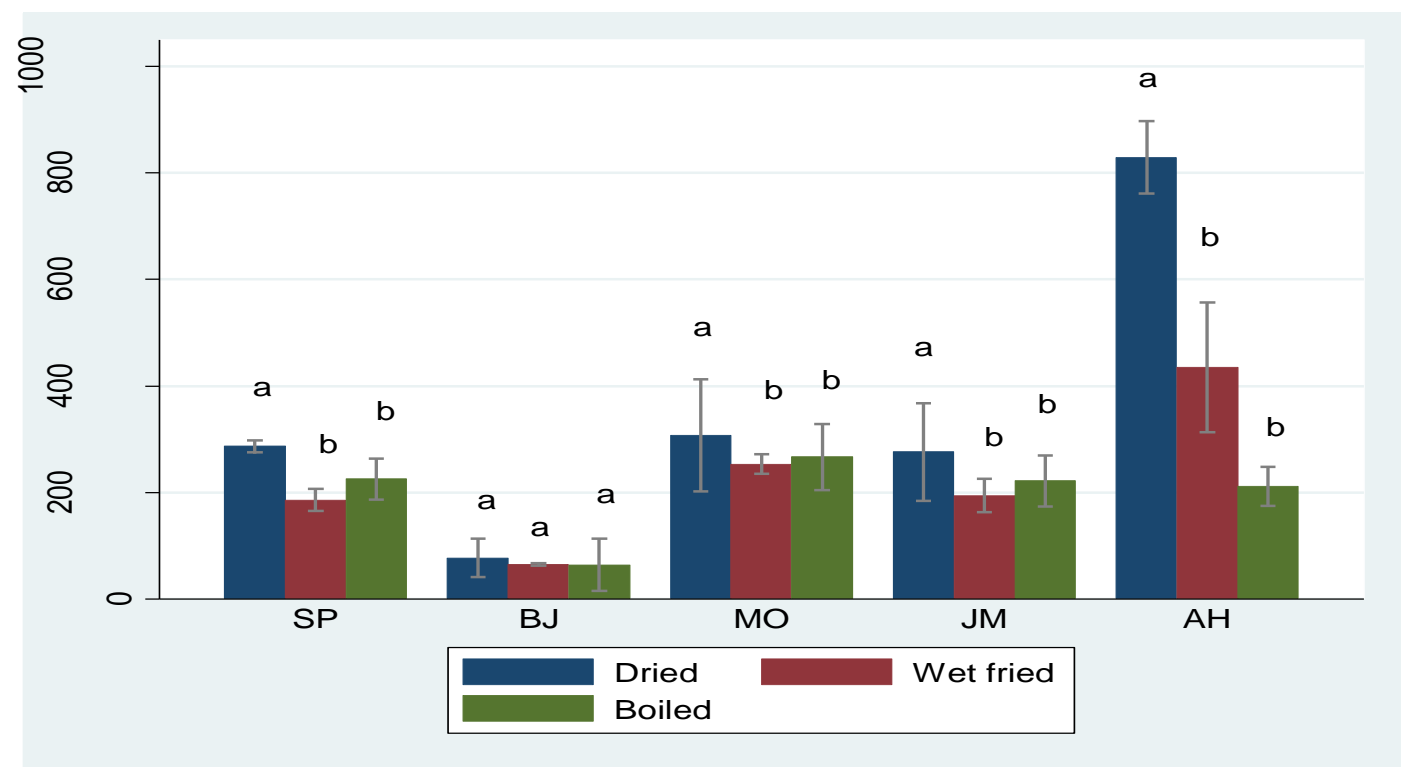

Figure 7. Mean amount of Oxalates in traditional vegetables as influenced by cooking methods. SP=sweet potato, $\mathrm{BJ}=\mathrm{Black}$ jack, $\mathrm{MO}=$ Moring a oleifera, $\mathrm{JM}=\mathrm{Jute}$ mallow and $\mathrm{AH}=$ Amaranthus hybridus. Mean $\pm \mathrm{SD}$ values in the same group followed by the same superscripts are not significantly different at $\alpha=0.05$ using Bonferroni

ANOVA test

Table 4. Phytate content $(\mathrm{mg} / 100 \mathrm{~g})$ in traditional vegetables as influenced by cooking methods

Entries are Mean $\pm \widehat{\mathrm{SD}}$

\begin{tabular}{llll}
\hline Vegetable leaves & Dried $(\mathbf{n}=\mathbf{3})$ & Wet fried $(\mathbf{n}=\mathbf{3})$ & Boiled $(\mathbf{n}=\mathbf{3})$ \\
\hline Sweet potato & $129.15 \pm 42.47^{\mathrm{a}}$ & $123.91 \pm 13.55^{\mathrm{a}}$ & $118.48 \pm 11.41^{\mathrm{a}}$ \\
Black jack & $124.95 \pm 52.25^{\mathrm{a}}$ & $84.98 \pm 13.57^{\mathrm{a}}$ & $99.35 \pm 40.76^{\mathrm{a}}$ \\
Moringa oleifera & $99.80 \pm 10.29^{\mathrm{a}}$ & $69.28 \pm 5.46^{\mathrm{b}}$ & $87.11 \pm 0.36^{\mathrm{a}}$ \\
Jute mallow & $86.64 \pm 12.51^{\mathrm{a}}$ & $43.95 \pm 12.51^{\mathrm{b}}$ & $44.75 \pm 8.14^{\mathrm{b}}$ \\
Amaranth hybridus & $72.17 \pm 18.19^{\mathrm{a}}$ & $37.90 \pm 14.11^{\mathrm{a}}$ & $12.42 \pm 9.63^{\mathrm{b}}$ \\
\hline
\end{tabular}

Values in the same row followed by the same superscripts are not significantly different at $\alpha=0.05$ using Bonferroni ANOVA test.

\subsubsection{Effects of Wet Frying and Boiling on Tannins Content}

The results for tannins content in the five traditional vegetables and its respective wet fried and boiled counterparts for each vegetable are presented in Table 5. The amount of tannins in the uncooked dry vegetables ranged from $42.94 \mathrm{mg} / 100 \mathrm{~g}$ to $77.16 \mathrm{mg} / 100 \mathrm{~g}$ on dry weight basis. The mean amount of tannins in these dry uncooked vegetables were $42.94 \mathrm{mg} / 100 \mathrm{~g}, 47.91 \mathrm{mg} / 100 \mathrm{~g}, 49.53 \mathrm{mg} / 100 \mathrm{~g}, 61.18 \mathrm{mg} / 100 \mathrm{~g}$ and $77.16 \mathrm{mg} / 100 \mathrm{~g}$ in jute mallow, Amaranth hybridus, Moringa oleifera, sweet potato leaves and black jack leaves respectively. Boiling significantly reduced $(\mathrm{P} \leq 0.05)$ the amount of tannins in jute mallow and sweet potato leafy vegetables. There was no significant loss of tannins due to wet frying in all the vegetables. Boiling reduced the amount of 
tannins in sweet potato leaves and Amaranthus hybridus by $42.69 \%$ and $36 \%$ respectively. Wet frying reduced the amount of tannins in black jack leafy vegetables by $31 \%$. Significant losses of tannins were reported by Jugran, A. K., \& Chaudhary, W. Y.,2016 in Peeonia emodi leaves after boiling the leaves from different stages of growth. The losses of tannins due to boiling and frying are attributed to thermal degradation of tannins during cooking as reported by Gunathilake et al., 2018. In this study, the amount of tannins in wet fried jute mallow increased by $8.09 \%$ compared to the dry uncooked jute mallow. The amount of tannins in Moringa oleifera leafy vegetables increased by $13.79 \%$ and $30.67 \%$ as a result of wet frying and boiling the vegetables for ten minutes respectively. These results agrees with Gunathilake et al.,2018 where it was found that in some vegetables, tannins content increase due to breakdown of the complex tannins compounds present in the vegetables during heat processing to simple tannins. Also, increase in total polyphenols such as tannins during thermal processing might be due to the liberation of polyphenols from the intracellular protein complexes, changes in plant cell structure, matrix modifications, or the inactivation of the polyphenol oxidases (Gunathilake et al., 2018).

Table 5. Tannins content (mg/100g DM) in traditional vegetables as influenced by cooking methods

\begin{tabular}{llll}
\hline Vegetable leaves & Dried $(\mathbf{n}=3)$ & Wet fried $(\mathbf{n}=\mathbf{3})$ & Boiled $(\mathbf{n}=\mathbf{3})$ \\
\hline Sweet potato & $61.18 \pm 15.48^{\mathrm{a}}$ & $52.73 \pm 25.96^{\mathrm{a}}$ & $35.06 \pm 8.84^{\mathrm{b}}$ \\
Black jack & $77.16 \pm 23.27^{\mathrm{a}}$ & $53.42 \pm 14.448^{\mathrm{a}}$ & $70.56 \pm 4.51^{\mathrm{a}}$ \\
Moringa oleifera & $49.53 \pm 7.10^{\mathrm{a}}$ & $56.36 \pm 13.52^{\mathrm{a}}$ & $64.72 \pm 8.65^{\mathrm{a}}$ \\
Jute mallow & $42.94 \pm 17.48^{\mathrm{a}}$ & $46.37 \pm 12.46^{\mathrm{a}}$ & $32.98 \pm 19.58^{\mathrm{b}}$ \\
Amaranth hybridus & $47.91 \pm 3.53^{\mathrm{a}}$ & $33.87 \pm 11.19^{\mathrm{a}}$ & $30.50 \pm 6.01^{\mathrm{a}}$ \\
\hline
\end{tabular}

Entries are mean $\pm \mathrm{SD}$

Values in the same row followed by the same superscripts are not significantly different at $\alpha=0.05$ using Bonferroni ANOVA test.

\section{Conclusions}

The findings from the present study indicate that minerals, crude fats, beta-carotene, vitamin C, oxalates, phytates and tannins of selected five traditional vegetables are altered during common cooking practices; boiling and wet frying. Wet frying reduced the amount of nutrients such as iron, zinc, copper, calcium, magnesium and beta-carotene in most of the vegetables as compared to boiling. On the other hand, wet frying retained and preserved the amount of Vitamin $\mathrm{C}$ in all the vegetables while boiling reduced vitamin $\mathrm{C}$ content in all the vegetables. Wet frying significantly increased the amount of crude fats in all the vegetables while boiling slightly reduced crude fats in the vegetables. Boiling has shown to have varying effects on iron, zinc, calcium, magnesium, and beta-carotene depending on the type of leafy vegetable. Boiling retained significant amounts of beta-carotene in all the vegetables. Both boiling and wet frying reduced the amount of antinutrients (oxalates, phytates and tannins) in most of the vegetables. Boiling had the highest effect to reduce tannins as compared to wet frying. The results of the study can be used for making recommendations on food processing methods to preserve the health benefits of the studied vegetables and reduce the antinutrients of the vegetables.

\section{Acknowledgements}

Support for this research was made possible through a capacity building competitive grant " Training the next generation of Scientists" provided by Carnegie Cooperation of New York through the Regional Universities Forum for Capacity Building in Agriculture (RUFORUM).

\section{References}

Akwaowo, E. U., Ndon, B. A., \& Etuk, E. U. (2000). Minerals and antinutrients in pumpkin (Telfairia occidentalis Hook f.). Food Chemistry, 70, 0-5. https://doi.org/10.1016/S0308-8146(99)00207-1

Armesto, J., Gómez-limia, L., Carballo, J., Martínez, S., Armesto, J., Gómez-limia, L., ... Armesto, J. (2019). Effects of different cooking methods on the antioxidant capacity and flavonoid , organic acid and mineral contents of Galega Kale (Brassica oleracea var. acephala cv. Galega), International Journal of Food Sciences and Nutrition, 70(2). https://doi.org/10.1080/09637486.2018.1482530

Azizah A. H., Wee, K. C., Osman, A., \& Azizah, M. (2009). Effect of boiling and stir frying on total phenolics , carotenoids and radical scavenging activity of pumpkin (Cucurbita moschato). International Food Research Journal, 16.

Camire, A. L., \& Clydesdale, F. M. (2006). Analysis of Phytic Acid in Foods by HPLC. Journal of Food Science, 47(2), 575-578. https://doi.org/10.1111/j.1365-2621.1982.tb10126.x 
Yu, L., Peng, X. X., Yang, C., Liu, Y. H., \& Fan, Y. P. (2002). Determination of oxalic acid in plant tissue and root exudate by reversed phase high performance liquid chromatography. Fenxi Ниахие, 30, 1119-1122.

CRS. (2017). Assessment on Availability of African Indigenous Leafy Vegetables in Malawi and Zambia, (October).

Ebrahimzadeh, M. A., Pourmorad, F., \& Bekhradnia, A. R. (2008). Iron chelating activity, phenol and flavonoid content of some medicinal plants from Iran. African Journal of Biotechnology, 7(18), 3188-3192. https://doi.org/10.5897/AJB08.476

Essack, H., Odhav, B., \& Mellem, J. J. (2017). Screening of traditional South African leafy vegetables for specific anti-nutritional factors before and after processing. Food Science and Technology, 37(3), 462-471.

Etcheverry, P., Grusak, M. A., \& Fleige, L. E. (2012). Application of in vitro bioaccessibility and bioavailability methods for calcium, carotenoids, folate, iron, magnesium, polyphenols, zinc, and vitamins $\mathrm{B}_{6}, \mathrm{~B}_{12}, \mathrm{D}$, and E. Front. Physiol., 3(August), 1-22. https://doi.org/10.3389/fphys.2012.00317

Gunathilake, K. D. P. P., Ranaweera, K. K. D. S., \& Rupasinghe, H. P. V. (2018). Effect of Different Cooking Methods on Polyphenols , Carotenoids and Antioxidant Activities of Selected Edible Leaves. Antioxidants, 7(9), 117. https://doi.org/10.3390/antiox7090117

Habwe, F. O., Walingo, M. K., Abukutsa-onyango, M. O., \& Oluoch, M. O. (2009). Iron content of the formulated East African indigenous vegetable recipes. African Journal of Food Science, 3(12), 393-397.

Jugran, A. K., \& Chaudhary, W. Y. (2016). Effect of Processing and Storage Methods on the Nutritional , Anti-nutritional, and Anti-oxidant Properties of Paeonia emodi, Wall. ex. Royle. Applied Biochemistry and Biotechnology, 180(2), 322-337. https://doi.org/10.1007/s12010-016-2101-0

Lewu, M. N., Adebola, P. O., \& Afolayan, A. J. (2009). Effect of cooking on the mineral and antinutrient contents of the leaves of seven accessions of Colocasia esculenta (L.) Schott growing in South Africa, 7(October). Journal of Food Composition and Analysis, 23(5), 389-393.

Masrizal, M., \& Giraud, D. (1996). RETENTION OF VITAMIN C, IRON, AND $\beta$ - CAROTENE IN VEGETABLES PREPARED USING DIFFERENT COOKING METHOD. Journal of Food Quality, 20(5), 403-418. https://doi.org/10.1111/j.1745-4557.1997.tb00483.x

Maundu, P. (2014). Current knowledge on Amaranthus spp: research avenues for improved nutritional value and yield in leafy amaranths in sub-Saharan Africa. Euphytica, 197(3), 303-317. https://doi.org/10.1007/s10681-014-1081-9

Mcewan, R., Shangase, F. N., Djarova, T., \& Opoku, A. R. (2014). Effect of three processing methods on some nutrient and anti-nutritional factor constituent of Colocasia esculenta (Amadumbe). AFRICAN JOURNAL OF FOOD SCIENCE, 8(May), 286-291. https://doi.org/10.5897/AJFS2013.1139

Millet, P. (2013). Effects of Malting and Fermentation on Anti-Nutrient Reduction and Protein Digestibility of Red Sorghum, White Sorghum and, Pearl Millet. Journal of Food Research, 2(1), 41-49. https://doi.org/10.5539/jfr.v2n1p41

Odhav, B., Beekrum, S., Akula, U., \& Baijnath, H. (2007). ARTICLE IN PRESS Preliminary assessment of nutritional value of traditional leafy vegetables in KwaZulu-Natal, South Africa. Journal of Food Composition and Analysis, 20(5), 430-435. https://doi.org/10.1016/j.jfca.2006.04.015

Ogliano, V. I. F., \& Ellegrini, N. I. P. (2008). Effects of Different Cooking Methods on Nutritional and Physicochemical Characteristics of Selected Vegetables. Journal of Agricultural and Food Chemistry, 56(1), 139-147. https://doi.org/10.1021/jf072304b

Ojo, O. O., Taiwo, K. A., Scalon, M., Oyedele, D. J., \& Akinremi, O. O. (2016). Influence of pre-treatments on some nutritional and anti-nutritional contents of Solanum macrocarpon (Gbagba), (August).

Olawoye, B. T., \& Gbadamosi, S. O. (2017). Effect of different treatments on in vitro protein digestibility, antinutrients , antioxidant properties and mineral composition of Amaranthus viridis seed. Cogent Food \& Agriculture, 94(1), 1-14. https://doi.org/10.1080/23311932.2017.1296402

Otunola, G. A., \& Afolayan, A. J. (2017). Nutritional evaluation of Kedrostis africana (L.) Cogn: An edible wild plant of South Africa. Asian Pacific Journal of Tropical Biomedicine, 7(5), 443-449.

https://doi.org/10.1016/j.apjtb.2017.01.016

Passone, M. A., Resnik, S. L., \& Etcheverry, M. G. (2005). In vitro effect of phenolic antioxidants on 
germination, growth and aflatoxin B1 accumulation by peanut Aspergillus section Flavi. Journal of Applied Microbiology, 99(3), 682-691. https://doi.org/10.1111/j.1365-2672.2005.02661.x

Rodriguez-Amaya, D., \& Kimura, M. (2004). HarvestPlus Handbook for Carotenoid Analysis. HarvestPlus Technical Monographs, 59.

Singh, R. R., \& Harshal, A. (2016). Effects of Cooking on Content of Vitamin C in Green Leafy Vegetables. Scholars Journal of Agriculture and Veterinary Sciences, 3(6), 416-423. https://doi.org/10.21276/sjavs.2016.3.6.4

Traoré, K., Parkouda, C., Savadogo, A., Ba, F., Regine, H., \& Yves, K. (2017). Effect of processing methods on the nutritional content of three traditional vegetables leaves: Amaranth, black nightshade and jute mallow. Food Science \& Nutrition, 5(6), 1139-1144. https://doi.org/10.1002/fsn3.504

Uusiku, N. P., Oelofse, A., Duodu, K. G., Bester, M. J., \& Faber, M. (2010). Nutritional value of leafy vegetables of sub-Saharan Africa and their potential contribution to human health: A review. Journal of Food Composition and Analysis, 23(6), 499-509. https://doi.org/10.1016/j.jfca.2010.05.002

Vikram, V. B., Ramesh, M. N., \& Prapulla, S. G. (2005). Thermal degradation kinetics of nutrients in orange juice heated by electromagnetic and conventional methods. Journal of Food Engineering, 69(1), 31-40. https://doi.org/10.1016/j.jfoodeng.2004.07.013

Yang, R. Y., \& Keding, G. B. (2009). Nutritional contributions of important African indigenous vegetables. African Indigenous Vegetables in Urban Agriculture. https://doi.org/10.4324/9781849770019

\section{Copyrights}

Copyright for this article is retained by the author(s), with first publication rights granted to the journal.

This is an open-access article distributed under the terms and conditions of the Creative Commons Attribution license (http://creativecommons.org/licenses/by/4.0/). 